\title{
Methodology of Risk Analysis and Regional Economic Security Threats
}

\author{
Olga M. Dyuzhilova ${ }^{1} \&$ Irina V. Vyakina ${ }^{1}$ \\ ${ }^{1}$ Tver State Technical University, Tver, The Russian Federation \\ Correspondence: Olga M. Dyuzhilova, Tver State Technical University, 22, Naberezhnaya Af. Nikitina, Tver, \\ 170026, The Russian Federation. Tel: 7-482-252-4900. E-mail: olga.dyuzhilova@mail.ru
}

Received: February 2, 2015 Accepted: March 2, 2015 Online Published: June 13, 2015

doi:10.5539/ass.v11n20p74 URL: http://dx.doi.org/10.5539/ass.v11n20p74

\begin{abstract}
The paper aims to research, diagnose and assess the risks and dangers of systemic nature threatening the region's economy. The purpose of the research is to analyze the theory and methodology of economic security evaluation based on the diagnosis of regional industrial economic risks and identifying sources of risks and priorities for regional economic growth. The paper presents the rationale of regional economic security and reveals the contents of the risks and threats. Evaluation of the safety and profitability stability for regional industries has allowed to reveal the main priorities of economic development of the region and to identify "hot spots", the industries that could be a source of risk and destabilize the economic regional security. Tver region is an example, as its main indicators of economic activity are on the average level of development. It gives the possibility of using tools to support the strategy of economic security at the regional level.
\end{abstract}

Keywords: economic security, economic risks, direct damage, indirect damage, risk analysis

\section{Introduction}

Safety is a condition of any objects and subjects' immunity, lacking of both internal and external threats. It is usually considered as an absence of potential possibility of threats appearance and different negative impacts. It is a scientific category presenting an integral form of immunity, reliability, stability and vitality of various subjects, objects and systems.

Security assurance is based on three main principles: eliminating and minimizing danger sources' effects, increasing the protection level, making conditions for the further development.

Any type of human activity associates with a danger level which is characterized by the risk concept (Barseghyan, Molinari, O'Donoghue, \& Teitelbaum, 2013).

In order to have the possibility for comparing the level of danger of different management objects and making appropriate decisions, aiming at arrangements system implementation which generates the atmosphere of economic security, is necessary to develop a quantitative assessment of risk (Frolov, 2007).

\section{Methods and Materials}

Methodology of diagnosis and assessment of economic risks is based on the detailed analysis of the system's internal and external environment in order to generate maximal complete and objective data on potential economic risks and factors that cause them and their identification.

The assessment of an economic risk level is closely connected with the possibility of occurrence of any separate preliminary identified risk; it also depends on the amount of maximal potential financial losses including direct damage as well as lost profit, contractors' possible claims etc. As a result the level of risk is compared to the amount of expected revenues or losses.

Frolov K. V. (2007) is of opinion that "while making a decision which aims to solve security problems it is rational to use the following criterion: "prevented damage - security measures expenses - losses through invalid decisions" "( p. 21).

While analyzing different definitions of "risk" concept one can make a conclusion that they include a lot of other terms and conceptions, the most important ones are 'damage' and 'danger'. So in order to make the quantitative assessment of risk (R) possible, one should use the next formula (1): 
where $p_{i}$ is a possibility of a negative event, $\quad R=\sum_{i} p_{i} \cdot U_{i}$

$U_{\mathrm{i}}$ is an expected damage of this event,

It implies the existence of several possible unfavorable events with different damages and probabilities.

To determine economic risks and calculate the general risk level one should apply statistical methods based on the assessment of profitability fluctuation of regional industries (Tver region example) according to the data of the Federal Statistical Government, Tver branch (http://tverstat.gks.ru/).

For ensuring economic security it's obviously important to asses and predict the impact of all expected threats as well as economic and non-economic influences.

While calculating potential damage it is rationale to keep in mind the concept of direct, indirect and general damage. The direct damage consists of all losses of all national (regional) structures that are in the area of a negative event. The direct damage structure includes direct economic, environmental and social damages. The direct economic damage involves damages and losses of basic and circulating assets including expenses on the development restriction of the management object. The direct environmental damage implies soil and plants degradation, pollution, disappearance and undesirable appearance of water reservoirs, air pollution etc. The direct social damage includes human losses, living conditions changes etc.

The indirect damage (having the same structure as the direct one) includes out-of-direct influence zone losses. The indirect economic damage implies damages connected with the output and product range changes, efficiency level fluctuation, premature dropout of basic production facilities and assets, the necessity of management system reorganization etc.

The indirect environmental damage relates to the climate balance disturbance, animal losses and decrease in their population, natural resources deterioration. The indirect social damage is based on the following factors: human resources losses, manpower reallocation costs, changes in labor character and conditions, provision with social benefits and guarantees, consumption structure changes, public utilities and healthcare services provision.

One of the most important stages in risk and security analysis is an event sequence construction and assessment of damage at each level. The event tree analysis often demonstrates that moving from the initial event to its consequences, the impact of the former is declining while indirect damage assessment is getting more difficult. Therefore the expert's assessment of direct damage' shares can be rather useful for evaluating the indirect damage.

It should be noted that in some industries the direct and indirect damage correlation is $1: 30$, in some cases 1 to several hundreds.

The risk and security management methodology implies applying such analysis techniques that include all types of danger (engineering, economic, social etc.) and take into consideration today's and follow-up effects.

Risk, as an economic concept, has a subjective-objective nature. On the one hand, the economic system of any level operates in an external environment; its activity is influenced by a number of factors (almost non-dependent on subjective internal managerial decisions and actions). On the other hand, resources management efficiency results from internal managerial decisions made by managerial authorities and certain individuals. These decisions can be rather subjective and personal, their quality depend on people's expertise and their perception of risk. It raises the question of the necessity of diagnosis and assessment of potential internal and external threats which can do harm to the economic system sustainability. It's also important to detect those factors that damage vitally significant interests of the population and economic entities; and develop an efficient managerial mechanism responding to the revealed threats.

\section{Results}

We suppose that the internal structure of the economic security of any level consists of four criteria

1. economic independence which means the presence and possibility of managerial control over available resources (within authorities' limits)

2. stability and development consistency imply the presence of reliable institutional conditions and guarantees for economic activity which minimize the negative effects leading to the destabilization and threatening the sustainability.

3. self-development ability i.e. the potential for economic, scientific and social development, upgrading professional, educational and cultural skills as well as improving the population's standard of living 
4. level of integration, dependency and relations with the external environment that specify the system's ability to cooperate with the external environment and entities; identify an appropriate place in the foreign economic activity, the ability to adapt to changing external conditions. The criterion enables to achieve such development and efficiency level that guarantees competitiveness and equal rights in external transactions.

One should take into account that the businesses' economic security (as we've mentioned above) and the general level of the economic risk depend on both objective (external, non-dependent on businesses) and subjective (internal, dependent on expertise, personal qualities and physiological characteristics of the management staff) factors.

The internal (subjective) factors include: the level of financial stability, financial sovereignty and paying capacity; the state of material and technical basis; the structure of revenues and expenses; qualification, responsibility and experience of managerial and other staff.

The external (objective) factors defining the general level of the economic risk can be described as a general financial state of all cooperating entities; market situation; financial flows' sustainability; external environmental activities; the state and quality of the business situation including financial, lending, information, communication and transport infrastructure; political situation; economic stability in the region and in the country in whole etc.

Diagram 1 shows the structure of the economic security.



Figure 1. Economic security as the basis for ensuring security of social and economic system

In view of the fact that any risk events involve both direct economic and social damage and more significant indirect damage; ensuring economic security can become the basis for the security of social and economic system of any level, i.e. the economic security is "responsible" for all negative threats and situations that influence the country, region, industry etc.; it can cause some new problems.

The lack of proper mechanism regulating dangers which have a system character and threaten the whole economy, has led to some industries' degradation, first of all such basic infrastructure sectors as healthcare, 
education, law enforcement. The situation tears up the foundations of national economic development and ensuring regional and national economic security, that in its turn, decreases the standard and quality of living.

Excessive differences in living conditions can be interpreted as a violation of social equity principles and can lead to the growth of centrifugal forces and separatism, economic security deterioration in some regions and in the Russian Federation in whole.

The main problem of security assessment is to research social and economic risks as well as the environmental factors. The best known and investigated factor nowadays is the national level of economic security (Murphy, Topel, 2013). However socio- economic security and sustainable development are characterized by economic entities at meso- and micro- levels.

The economic security of any level is a complex cooperation system of society, government and economic entities, therefore the processes for ensuring security at international, national, regional and micro- economic levels are closely interrelated. Their integration is based on the similarity of these processes affecting different levels of economic security.

Economic security ensuring can't only rely on losses prevention, it's also essential to guarantee the expected level of revenues.

Considering the fact we can evaluate the degree of regional investment risks with the view of the sector structure of the regional economy (the Tver region example is an average level among the other Russian regions).

Taking into account the development of many socio-economic systems we can conclude that the risks $(R(t))$ are caused by unreasonable priorities, disrupting the sustainable development that in its turn weakens the regional position and threatens the existence of the management object.

It's quite rational to identify the individual peculiarities and points ("poles") of the region's economic growth. So it's necessary to define specific businesses which promote the general aim - the regional economic security ensuring. The balanced development of all parts is an essential requirement for the stable development of any system. Therefore all sub-targets can be integrated into the one general goal.

Thus the Tver region ranks 57 among 84 Russian regions in terms of Gross Regional Product (the amount of GRP index is much lower than the average Russian level). According to the data of 2012 the Tver GRP index per head is $57 \%$ that characterize the regional economy development and the Tver population's standard of living compared to the Russian Federation (the site's data1)

It's fair to say the production ratio of the added value varies a lot in the Russian regions, the levels of economic development and investment are highly differentiated.

For example the GRP index per head in the Tyumen and Sakhalin regions is about 1,3 million roubles while in the Chechnya and Ingushetia Republics it's only 80 thousand roubles.

In order to identify the most possible threats for the Tver region economic stability in terms of efficiency and fluctuation we are going to calculate the profitability and risks in view of different sectors (income variability).

The calculation of the average profitability and its variations, highlighting the risk level in the Tver region industries, is based on the statistics presented by the Federal Statistical Government, Tver branch for the period of $2005-2013$ (http://tverstat.gks.ru/).

The results are given in Table 1.

Table 1 . The average profitability and stability in terms of regional economic sectors (economic activity) of Tver region for the period of $2005-2013, \%$

\begin{tabular}{lccc}
\multicolumn{1}{c}{ Economic activity } & $\begin{array}{c}\text { The average } \\
\text { profitability }\end{array}$ & $\begin{array}{c}\text { Standard } \\
\text { deviation }\end{array}$ & $\begin{array}{c}\text { profitability variation } \\
\text { level }\end{array}$ \\
\hline $\begin{array}{l}\text { The total on regional economy } \\
\text { According to the types of economic activity: }\end{array}$ & $1,29 \%$ & $0,48 \%$ & $37,19 \%$ \\
Agriculture, hunting, forestry & $1,09 \%$ & $2,39 \%$ & $218,83 \%$ \\
Mining & $-3,96 \%$ & $7,77 \%$ & $196,17 \%$ \\
Processing industries & $2,26 \%$ & $1,31 \%$ & $58,08 \%$ \\
among them: & & & $53,44 \%$ \\
Food industry including beverages and tobacco & $1,36 \%$ & $0,73 \%$ & $212,18 \%$ \\
Textile and clothing manufacture & $-0,81 \%$ & $1,73 \%$ & \\
\hline
\end{tabular}




\begin{tabular}{lccc}
\hline Leather and shoemaking industry & $0,18 \%$ & $0,98 \%$ & $541,21 \%$ \\
Woodworking and wooden products industry & $-4,32 \%$ & $9,57 \%$ & $221,59 \%$ \\
pulp-and-paper industry, publishing and printing activities & $2,29 \%$ & $7,16 \%$ & $312,58 \%$ \\
Chemical industry & $2,34 \%$ & $2,55 \%$ & $108,81 \%$ \\
Rubber and plastics manufacturing & $7,15 \%$ & $2,07 \%$ & $29,01 \%$ \\
Other non- metal mineral products & $-3,44 \%$ & $10,45 \%$ & $303,39 \%$ \\
Metallurgy and metal products & $5,14 \%$ & $3,82 \%$ & $74,35 \%$ \\
Machinery and equipment manufacturing & $-1,60 \%$ & $6,64 \%$ & $414,13 \%$ \\
electrical and optical equipment & $4,74 \%$ & $7,33 \%$ & $154,76 \%$ \\
Vehicles manufacturing & $3,96 \%$ & $1,49 \%$ & $37,70 \%$ \\
Power, gas and water generation and distribution & $-0,35 \%$ & $0,54 \%$ & $155,57 \%$ \\
Building & $3,62 \%$ & $3,84 \%$ & $106,03 \%$ \\
Wholesaling and retailing; vehicles, motorbikes and home & & & $87,20 \%$ \\
appliances maintenance & $0,45 \%$ & $0,39 \%$ & $171,13 \%$ \\
Hotels and restaurants & $4,42 \%$ & $7,56 \%$ & $73,25 \%$ \\
Transport and communication & $2,91 \%$ & $2,13 \%$ & $63,17 \%$ \\
$\quad$ among them: & & & $530,41 \%$ \\
$\quad$ communication & $7,02 \%$ & $4,43 \%$ & $73,24 \%$ \\
$\quad$ transport & $0,16 \%$ & $0,83 \%$ & $55,53 \%$ \\
Real estate transactions, leasing, service sector & $1,93 \%$ & $1,42 \%$ & $78,15 \%$ \\
education & $0,44 \%$ & $0,24 \%$ & $380,32 \%$ \\
Healthcare and social services & $1,23 \%$ & $0,96 \%$ & $3,46 \%$ \\
\hline Municipal, social and personal services & $0,91 \%$ & $5 \%$ & \\
\hline
\end{tabular}

Notes: the information doesn't include small-scale businesses, banking and insurance sector, government-financed organizations.

Source: based on URL data: http://195.162.22.66/bgd2/DOCL1128/main.htm.

Table 2 defines changes-resistant industries in Tver region. The results show that for the period of $2005-2013$ in terms of income stability and risks, the rubber and plastics manufacturing as well as vehicles and equipment industries enjoyed the best situation among the other sectors of the Tver economy, especially in terms of profitability variation level.

Table 2. Tver region industries ranking (types of economic activity) for the period 2005-2013 in terms of profitability variation level

\begin{tabular}{cclcc}
\hline Stability level & Rank & \multicolumn{1}{c}{ Types of economic activity } & $\begin{array}{c}\text { Profitability } \\
\text { variation level }\end{array}$ & $29 \%$ \\
Sectors with the most stable & 1 & Rubber and plastics manufacturing & $38 \%$ \\
revenues & 2 & Vehicles and equipment manufacturing & $53 \%$ \\
(Profitability variation level less & 3 & Food industry including beverages and tobacco & $56 \%$ \\
than 70\%) & 4 & education & $63 \%$ \\
& 5 & communication & $73 \%$ \\
The average level of profitability & 6 & Real estate transactions, leasing, service sector & $74 \%$ \\
stability & 7 & Metallurgy and metal products & $78 \%$ \\
(Profitability variation level & 8 & Healthcare and social services & $87 \%$ \\
70-100\%) & 9 & Wholesaling and retailing; vehicles, motorbikes and & home & $106 \%$ \\
& & appliances maintenance & $109 \%$ \\
Unstable profitability & 10 & Building & $155 \%$ \\
(Profitability variation level & 11 & Chemical industry & $156 \%$ \\
100-200\%) & 13 & electrical and optical equipment & Power, gas and water generation and distribution & $171 \%$ \\
& 14 & Hotels and restaurants & $196 \%$ \\
The high level of profitability and & 15 & mining & Textile and clothing manufacture & $212 \%$ \\
\hline
\end{tabular}




\begin{tabular}{|c|c|c|c|}
\hline \multirow{9}{*}{$\begin{array}{c}\text { risks fluctuatuin } \\
\text { (Profitability variation level } \\
\text { more than 200\%) }\end{array}$} & 17 & Agriculture, hunting, forestry & $219 \%$ \\
\hline & 18 & Woodworking and wooden products industry & $222 \%$ \\
\hline & 19 & & $303 \%$ \\
\hline & & Other non- metal mineral products & \\
\hline & 20 & $\begin{array}{l}\text { pulp-and-paper industry, publishing and printing } \\
\text { activities }\end{array}$ & $313 \%$ \\
\hline & 21 & Municipal, social and personal services & $380 \%$ \\
\hline & 22 & Machinery and equipment manufacturing & $414 \%$ \\
\hline & 23 & transport & $530 \%$ \\
\hline & 24 & Leather and shoemaking industry & $541 \%$ \\
\hline
\end{tabular}

Source: the classification is based on Table 1, industries with negative profitability are marked

Along with the possibility of getting or losing revenues, the risk accounting implies the assessment of probable damage; arrangements' value aiming to prevent possible threats and risks; correlation of the concepts: "prevented damage" and "security implementation costs".

\section{Discussion}

Risk diagnosis based on profitability assessment should include risk occurrence evaluation in terms of its probability as well as the comparison of direct and indirect damages in case of happening. It raises the question of choosing the main directions of threats' and risk events' occurrence and the issue of priorities. The experts have different and rather contradictory opinions that provoke debates. Thus some of them think social and environmental risks are the most significant ones, others highlight market and financial risks, while the rest stress the importance of resources and technologies.

Thereupon we've prepared the classification of threats and risks. The reasons for the crisis occurrence caused by economic security threats can become various destabilization factors that can be divided into two modules according to the economic security structure described in table 1. The modules (economic and social threats and risks) have the following subgroups which can play more or less important role (according to different analysts).

Module 1. Economic risks and threats

I. RESOURCES AND TECHNOLOGIES (Lee, 2015):

- Deterioration of material and technical basis and technologies;

- Disruption of industrial potential;

- Reducing of research and development plans;

- Research staff disintegration;

- Reducing of proficiency level of engineering and research personnel;

- Irregular resources supplies;

- High level of raw material dependency etc.

II. MARKET (Sandri, 2014):

- Market structure changing;

- Sales markets loss;

- Market position falloff;

- Collapse of competitiveness and competitive advantages

- Monopolies' activities enhancing etc.

III. FINANCE (Gourio, 2013), (Bussière, Imbs, Kollmann, Rancière, 2013):

- Financial situation disturbance;

- Inability to pay;

- Financial liquidity decrease;

- High level of financial dependency; 
- Financial sustainability deterioration etc.

\section{Module 2. SOCIAL RISKS AND THREATS}

IV. SOCIAL (Imrohoroğlu, 2012), (Coile, 2011), (Dynan, 2009), (Clark, 2004) (Artigea, Dedrya, \& Pestieaub, 2014) (Chen \& Fang, 2013):

- Social situation decadency;

- migration;

- labor motivation decrease;

- living standards deterioration;

- high rate of social conflicts etc.

V. LEGISLATIVE (Volker \& Marion, 2010):

- economic criminality

- economic crimes growth;

- low level of legal safety;

- legislative framework changes

VI. ADMINISTARTIVE AND POLITICAL (Chomaa, Hanocha, Gummeruma, \& Hodsonb, 2013):

- changes in institutional conditions and guarantees of economic activity;

- political situation degradation;

- change of leadership and economic policy principles etc.

VII. ENVIRONMENTAL (Rangel, 2003), (Stern, 2013):

- natural environment deterioration;

- disturbance of natural balance;

- change of environmental standards, sanitary code etc.

Clusters I. II, III present economic risks and threats, clusters IV, V, VI, VII reveal social risks and threats. Any risks can be caused by both external and internal factors.

\section{Conclusion}

We suppose the necessary condition for solving risk and economic security problems are as follows:

- veracious assessment of economic and social system;

- various and reliable risk forecast for extreme social and economic situations;

- anticipatory (or well-timed) decision-making which supports social and economic system development at a proper level of economic security

Research aiming to create effective and reliable tools for ensuring economic security of any level should consider the dependency of the instruments on the complex of goals with corresponding indices, identifying the total development strategy. Risk and threat assessment should analyze not only the possibility of risk events and following direct and indirect damages, but also the necessity of getting income and probability of its loss.

\section{References}

Artigea, L., Dedrya, A., \& Pestieaub, P. (2014). Social security and economic integration. Economics Letters, 123(3), 318-322. http://dx.doi.org/10.1016/j.econlet.2014.02.027

Barseghyan, L., Molinari, F., O'Donoghue, T., \& Teitelbaum, J. C. (2013). The Nature of Risk Preferences: Evidence from Insurance Choices. American Economic Review, 103(6), 2499-2529. http://dx.doi.org/10. 1257/aer.103.6.2499

Bussière, M., Imbs, J., Kollmann, R., \& Rancière, R. (2013). The Financial Crisis: Lessons for International Macroeconomics. American Economic Journal: Macroeconomics, 5(3), 75-84. http://dx.doi.org/10.1257/ mac.5.3.75.

Chen, H.-J., \& Fang, I-H. (2013). Migration, social security, and economic growth. Economic Modelling, 32, 386-399. http://dx.doi.org/10.1016/J.ECONMOD.2013.02.026 
Chomaa, B., Hanocha, Y., Gummeruma, M., \& Hodsonb, G. (2013). Relations between risk perceptions and socio-political ideology are domain- and ideology- dependent. Personality and Individual Differences, 54(1), 29-34. http://dx.doi.org/10.1016/j.paid.2012.07.028

Clark, R. L. (2004). Social Security Financing: Facts, Fantasies, Foibles, and Follies. American Economic Review, 94(2), 182-186. http://dx.doi.org/10.1257/0002828041301678.

Coile, C. C., \& Levine, P. B. (2011). Recessions, Retirement, and Social Security. American Economic Review, 101(3), 23-28. http://dx.doi.org/10.1257/aer.101.3.23.

Dynan, K. E. (2009). Changing Household Financial Opportunities and Economic Security. Journal of Economic Perspectives, 23(4), 49-68. http://dx.doi.org/10.1257/jep.23.4.49.

Endress, L. H. (2015). Sustainable Economic Development. Resources, Environment and Institutions. Chapter 3 Scarcity, Security, and Sustainable Development (pp. 49-66). http://dx.doi.org/10.1016/B978-0-12-8003473.00003-0

Frolov, K. V. (2007). Risk analysis and safety issues (in 4 parts). Part 3. Applied issues of risk analysis of critical facilities (p. 806). MGF "Znanie", Mqscow.

Gourio, F. (2013). Credit Risk and Disaster Risk. American Economic Journal: Macroeconomics, 5(3), 1-34. http://dx.doi.org/10.1257/mac.5.3.1

Imrohoroğlu, S., \& Kitao, S. (2012). Social Security Reforms: Benefit Claiming, Labor Force Participation, and Long-Run Sustainability. American Economic Journal: Macroeconomics, 4(3), 96-127. http://dx.doi.org/10. 1257/mac.4.3.96.

Murphy, K. M., \& Topel, R. H. (2013). Some Basic Economics of National Security. American Economic Review, 103(3), 508-511. http://dx.doi.org/10.1257/aer.103.3.508.

Rangel, A. (2003). Forward and Backward Intergenerational Goods: Why Is Social Security Good for the Environment? American Economic Review, 93(3), 813-834. http://dx.doi.org/10.1257/000282803322157 106

Sandri, D. (2014). Growth and Capital Flows with Risky Entrepreneurship. American Economic Journal: Macroeconomics, 6(3), 102-123. http://dx.doi.org/10.1257/mac.6.3.102

Stern, N. (2013). The Structure of Economic Modeling of the Potential Impacts of Climate Change: Grafting Gross Underestimation of Risk onto Already Narrow Science Models. Journal of Economic Literature, 51(3), 838-859. http://dx.doi.org/10.1257/jel.51.3.838.

Volker, A., \& Marion, H. (2010). Income redistribution and criminality in a growing economy. International Review of Law and Economics, 30(4), 338-344. http://dx.doi.org/10.1016/j.irle.2010.08.002

\section{Copyrights}

Copyright for this article is retained by the author(s), with first publication rights granted to the journal.

This is an open-access article distributed under the terms and conditions of the Creative Commons Attribution license (http://creativecommons.org/licenses/by/3.0/). 